\title{
PERAN MANAJER KEPALA SEKOLAH DALAM MENGELOLA EKSTRA- KURIKULER KURIKULUM 2013
}

\author{
Abdul Majir ${ }^{1} \&$ Fransiskus Nendi ${ }^{2)}$ \\ 1) Dosen Program Studi PGSD STKIP St. Paulus \\ e-mail:Abdulmajir@gmail.com \\ 2) Dosen Program Studi Pendidikan Matematika STKIP Santu Paulus \\ e-mail: fransiskusnendi@gmail.com
}

\begin{abstract}
Abstrak
Latar belakang penelitian adanya kewajiban setiap sekolah/madrasah melaksanakan kegiatan ekatrakurikuler wajib kepramukan dalam kurikulum 2013.Tujuanan dilaksanakan penelitian ini, untuk mengetahui tentang peran manajer kepala sekolah MAN 2 Manggarai dalam mengelola ekstrakurikuler kurikulum 2013 terhadap peningkatan mutu sekolah.

Penelitian ini merupakan penelitian deskriptif kualitatif dengan desain penelitian studi kasus yang difokuskan pada satu fenomena saja yang dipilih untuk dipahami secara mendalam, dengan mengabaikan fenomena-fenomena lainnya. Pengumpulan data dalam penelitian ini menggunakan metode wawancara terstruktur, observasi partisipasi dan studi dokumentasi.Instrumen yang digunakan dalam penelitian adalah peneliti sendiri dan didukung instrumen lain yaitu lembaran pedoman wawancara dan lembaran pedoman observasi serta kamera.

Untuk mengetahui keabsahan data, penelitimenggunakan teknik perpanjangan keikutsertaan, ketekunan dalam pengamatan dantrianggulasi. Teknik analisis data yang digunakan adalah analisis kualitatifinteraktif.

Berdasarkan hasil penelitian dan analisis data, dapat rumuskan lima kesimpulan yaitu: 1) Peranmanajer Kepala Sekolah MAN 2 Manggarai mulai dari proses perencanaan, proses pengorganisasian, proses pelaksanaan, dan proses evaluasi sangat baik, 2) mutu sekolah terwujud,perlunya komitmen tinggi terhadap perubahan zaman, 3) Selalu mengembangkan kemampuan mengajar dan memilki komitmen tinggi terhadap tugas, 4) Tanggungjawab terhadap kerja, mengembangkan diri, peningkatan kinerja, 5) Membangun kerjasama internal (sekolah) dan eksternal (pemerintahdan masyarakat atau komite sekolah)
\end{abstract}

Kata kunci:peranmanajer,kepalasekolah, ekstrakurikuler, kurikulum 2013 dan mutusekolah

\begin{abstract}
The upbringing of this study is the obligation of every school/madrasah to carry out the extracurricular scouting activities of the 2013 curriculum. The goalmouth of this study is to know the role of the headmaster of MAN 2 Manggarai in supervision the extracurricular activity of 2013 curriculum to improve the school quality.

This research is a qualitative descriptive research with the case study investigation project is focus on a chosen phenomenon to be fathomed deeply, nonetheless other phenomena.
\end{abstract}


Data collection of this research is using edifice interview technique, accomplice observation and documentation study. The used instrument in this research is the researcher himself and is supported by other instruments such as interview guide sheets and observation charts and camera.

To determine the validity of the data, researcher used extension techniques of participation, persistence in observation and triangulation. Data analysis technique used is interactive qualitative analysis.

Based on the research results and data analysis, five conclusions can be formulated as: 1) The role of manager,the Principal of MAN 2 Manggarai from the planning process, organizing process, implementation process, and evaluation process werevery good, 2) the quality of school is achieved needasahigh commitment towardstransformation (4) Responsibility for working, selfdevelopment, performance improvement, 5) buildingan internal (school) and external cooperation (government and community or school committee)

Keywords: role of manager, principal, extra-curricular of 2013curriculum and school eminence.

\section{PENDAHULUAN}

Manajemen

pendidikan

merupakan hal yang sangat penting dalam bidang mengembangkan pendidikan. Dengan manajemen, kinerja sebuah organisasi dapat berjalan secara maksimal. Demikian juga dengan lembaga pendidikan. Dengan manajemen yang baik, maka sebuah institusi pendidikan akan dapat berkembang secara optimal sebagaimana diharapkan. Manajemen pendidikan merupakan titik sentral untuk mewujudkan kualitas pendidikan. Kualitas pendidikan mewujudkan tujuan pembangunan sumber daya manusia (SDM) dalam berbangsa dan bernegara. Oleh karena itu, penting untuk dipertimbangkan bagi semua lembaga pendidikan untuk memiliki tenaga pendidikan dan kependidikan yang profesional.

Dalam mengelola pendidikan diperlukan kualitas personil yang memadai.Penempatan personil yang sesuai dengan kompetensi, merupakan keharusan untuk mewujudkankinerja yang efektif dan efisien. Sebab faktor manajemen merupakan jembatan yang berpengaruh terhadap mutu sekolah sehingga menhasilkan siswa yang berkualitas.Seperti dalam penerapan kurikulum intra dan ekstra membutuhkan pengelola yang profesional. Sebab kurikulum ekstrakurikuler maupun intra-kurikuler merupakan satu kesatuan yang saling menunjang untuk memenuhikebutuhan siswa yang berkaitan langsung denganpengetahuan dan 
pengalaman.Melalui kegiatan ekstrakurikuler akanmemberikan sumbangan yang berarti bagi siswauntuk mengembangkan minat-minat baru,menanamkan tanggung jawab sebagai warganegara, melalui pengalaman-pengalaman danpandangan-pandangan kerja sama dan terbiasadengan kegiatan mandiri.Sekolah memiliki fungsi membentuk potensi peserta didik agar sesuai dengan norma atau budaya serta memiliki kompetensi yang sesuai dengan tujuan pendidikan nasional. Untuk mengembangkan potensi peserta didik tersebut, lembaga pendidikan pada setiap jenjang secara sistemik melakukan inovasi dan pengembangan terhadap kurikulum yang ada.

Salah satu inovasi yang dilakukan sekolah adalah kegiatan ekstrakurikuler yang wajib diikuti oleh setiap peserta didik. Kegiatan ekstra-kurikuler merupakan program pendidikan yang alokasi waktunya tidak ditetapkan dalam kurikulum, tetapi perangkat pelengkap kurikulum, yang perlu disusun dan dituangkan dalam rencana kerja tahunan/kalender pendidikan di sekolah. Kegiatan ekstra-kurikuler merupakan "jembatan" yang menyambungkan

perkembangan peserta didik yang beragam seperti perbedaan budaya dan sikap, kemampuan, dan kreativitas. Melalui kegiatan ekstrakurikuler di sekolah peserta didik dapat bersosialisasi, kerjasama dengan peserta didik lain, membagi serta menerima pengalaman untuk mengembangkan potensi yang dimiliki oleh masing-masing peserta didik sehingga tujuan pendidikan nasiona dapat sesuai harapan bangsa dan Negara.

Secara konstitusional, pendidikan nasional: “...berfungsi mengembangkan kemampuan dan membentuk watak serta peradaban bangsa yang bermartabat dalam rangka mencerdaskan kehidupan bangsa, bertujuan untuk berkembangnya potensi peserta didik agar menjadi manusia yang beriman dan bertakwa kepada Tuhan Yang Maha Esa, berakhlak mulia, sehat, berilmu, cakap, kreatif, mandiri, dan menjadi warga negara yang demokratis serta bertanggung jawab (Pasal 3 Undang-Undang Nomor 20 Tahun 2003 Tentang Sistem Pendidikan Nasional). Untuk mewujudkan fungsi pendidikan yang diamanatkan dalam konstitusi tersebut, setiap jenjang 
pendidikan mulai dari pendidikan anak usia dini (PAUD) sampai perguruan tinggi (PT) diwajibkan adanya kegiatan intrakurikuler (kegiatan terstruktur dan terjadwal sesuai dengan cakupan dan tingkat kompetensi muatan atau matapelajaran), ko-kurikuler (kegiatan penugasan terstruktur terkait muatan atau mata pelajaran), dan ekstrakurikuler (kegiatan terorganisasi/terstruktur di luar struktur kurikulum setiap tingkat pendidikan yang dapat menunjang tujuan pendidikan).

Kegiatan ekstrakurikur memiliki jenis dan beragam sesuai karakteristik sekolah dan kebutuhan daerah dimana sekolah itu berada.Selama kegiatan ekstra-kurikulertersebut tidak menyimpang dari falsafah pendidikan yaitu Pancasila. Dalam implementasi kegiatan ekstra-kurikuler di sekolah, kepala sekolah sebagai manajer harus mampu mengembangkan proses manajemen pendidikan yang terarah, terpadu, terus menerus, dan berkesinambungan. Terutama dalam hal mengelola para guru, staf dan sarana dan prasana pendukung dan penunjang dalam proses kegiatan pembelajaran ekstra-kuriler. Sarana dan prasarana memerlukan sistem pengelolaan yang terstandar mencakup perencanaan, pengadaan, pendataan, pemanfaatan dan pemeliharaan dalam pelaksanaan kegiatan.

Dalam pelaksanaan kurikulum 2013, pendidikan kepramukaan merupakan kegiatan ekstra-kurikuler wajib dilaksanakan mulai dari Sekolah Dasar (SD) sampai Menengah Atas (SMA/sederajat).

Pendidikan kepramukaan sebagai wahana penguatan psikologis-sosial-kultural (reinfocement) perwujudan sikap dan keterampilan kurikulum 2013 yang secara psikopedagogis koheren dengan pengembangan sikap dan kecakapan dalam pendidikan Kepramukaan. Dengan demikian pencapaian Kompetensi Inti Sikap Spiritual (KI 1), Sikap Sosial (KI 2), dan Keterampilan (K3) memperoleh penguatan bermakna (meaningfull learning) melalui fasilitasi sistemikadaptif pendidikan kepramukaan di lingkungan satuan pendidikan. (Pedoman penyelenggaraan Ekstrakurikuler Wajib Pendidikan Kepramukaan, 2014:1)

Namun kenyataan yang dapat kita amati di setiap sekolah baik sekolah dasar (SD) maupun Sekolah 
Menengah Atas (SMA/Sederajat) masih terdapat sekolah yang belum melaksanakan kegiatan ekstrakurikuler kepramukaan sebagaimana semangat dari pengembangan kurikulum 2013 tersebut.Berdasarkan observasi pada studi pendahuan di Madrasah Aliyah Negeri (MAN) 2 Manggarai Ruteng Flores NTT pada tanggal 9 sampai 11 November 2017 masih ditemukan: (1) kegiatan ekstrakurikuler belum optimal berjalan sesuai harapan kurikulum 2013, (2)perencanaan program ekstrakurikuler pramuka, belum sesuai harapan kurikulum 2013, (3)pelaksanaan ekstrakurikuler pramuka belum ada kepastian model implmentasi ekstrakurikuler pramuka, (4) evaluasi akhir/penilaian belum menggunakan standar yang baku.

Berdasarkan temuan di atas, masalah yang menjadi fokus dalam penelitian ini adalah:Peran Manajerial Kepala Sekolah Dalam Mengelola EkstraKurikuler. Untuk memperoleh teori subtantif dari fokus tersebut dibuat bibuat 2 sub fokus: (1) peran manajerial kepala sekolah dalam kegiatan ekstrakuriuler, (2)upaya kepala sekolah Madrasah AliyahNegeri 2 Ruteng dalam mengelolah ekstra- kurikuler keparamukaan kurikulum 2013.

Konsep tentang manajerial, seperti Theodorus Hani Handoko (1995: 13) menjelaskan bahwa praktek manajerial adalah kegiatan yang dilakukan oleh manajer. Sedangkan Siagian (2002: 63) mengemukakan bahwa "Manajerial skill adalah keahlian menggerakkan orang lain untuk bekerja dengan baik". Karena kemampuan manajerial sangat erat kaitan dengan manajemen kepemimpinan yang efektif, maka pada hakekatnya manajemen adalah masalah interaksi antara manusia baik secara vertikal maupun horizontal.Dengan demikian kepemimpinan dapat dikatakan sebagai perilaku memotivasi orang lain untuk bekerjasama kearah pencapaian tujuan tertentu.

Sedangkan kepala sekolah merupakan seorang tenaga fungsional guru yang diberi tugas untuk memimpin suatu sekolah, di mana diselenggarakan proses belajarmengajar, menjadi figur penengah dan sumber informasi bagi bawahannya serta mampumemecahkan masalah yang terjadi di sekolah yang dipimpinnyaWahjosumidjo (2005: 
83).Selanjutnya Kepala sekolah merupakan orang terpenting dalam pengembang dan peningkatan mutu sekolah dan prestasi siswa dapat tercapai secara maksimal.

Dalam Peraturan Menteri Pendidikan Nasional RI No 13 Tahun 2007 tentang Kepala sekolan menjelaskan:

“... Kepala sekolah merupakan pejabat formal di sekolah, dikarenakan

pengangkatannya melalui suatu proses dan prosedur yang didasarkan atas peraturan yang berlaku. $\mathrm{Hal}$ ini dapat ditunjukkan dengan adanya kualifikasi dan kompetensi. Sedangkan kompetensi yang harus dimiliki oleh kepala sekolah diantaranya kompetensi kepribadian, manajerial, kewirausahaan, supervisi, dan sosial".

Sedangkan kepala sekolah

sebagai seorang manajer di sekolah merupakan salah satu kompetensi kepala sekolah sebagaimana pendapat Kats dan Dill (1984), mengutip pendapat Goston (1976) menjelaskan:

"seorang tenaga fungsional (guru) yang diberi tugas tambahan untuk memimpin suatu sekolah di mana diselenggarakan proses belajar mengajar atau tempat di mana terjadi interaksi antara guru yang memberi pelajaran kepada peserta didik melalui prosedur serta persyaratanpersyaratan tertentu berdasarkan integitas dan pengalamannya. kompetensi manajerial kepala sekolah tersebut ada tiga yaitu:(1)Ketrampilan konseptual ,artinya kemampuan/ketrampilan yang diperlukan seorang pemimpin untuk memahami dan mengoprasikan organisasi. (2) Ketrampilan hubungan manusiawi, dapat diartikan sebagai ketrampilan untuk bekerja sama, memotivasi dan memimpin organisasi, (3)Ketrampilan teknik artinya ketrampilan dalam menggunakan pengetahuan, metode, strategi, teknik tertentu dalam organisasi"

Menurut Katz dan Kahn (Agus, 2010), berkaitan dengan peran manajerial kepala sekolah dibagi menjadi tiga yaitu: (a) teknis, berkaitan dengan perencanaan, pengorganisasian, koordinasi, pengawasan, (b) hubungan sosial, berkaitan dengan hubungan antar manusia dan keterampilan yang dimiliki, dan (c) konseptual, menekankan pengetahuan dan keterampilan terkait layanan dari organisasi.

Berdasarkan uraian di atas, maka dapat disimpulkan bahwa secara teoritis peran kompetensi manajerial kepala sekolah adalah: seorang guru 
memiliki kelebihan dari guru yang lainnya dalam hal ketrampilan atau kecakapan, pengalaman, kualifikasi dan kepribadian dalam megelolah proses manajemen di sekolah yaitu kegiatan perencanaan yang meliputi penentuan tujuan organisasi, penjabaran tugas/pekerjaan, pembagian tugas, (2) kegiatan pengarahan, atau menggerakkan anggota organisasi untuk bekerja memutar roda organisasi, pelaksanaan: kerjasama dengan semua stakeholder, (4) pengawasan yang berarti memantau hasil pekerjaan sebagai umpan balik dengan standar yang telah ditentukan dalam perencanaan awal. Dengan demikian seorang guru dapat menjadi kepala sekolah/ manajer apabila guru yang bersangkutan memiliki kompetensi teknis,kemampuan untuk memahami perilaku stakeholder dan proses kerja sama sertamemiliki kemampuan konseptual untuk semua kepentingan sekolah.

\section{KEGIATAN EKSTRA-KURIKULER KEPRAMUKAAN}

Kegiatan ekstra-kurikuler di sekolah adalah program pendidikan yang alokasi waktunya tidak ditetapkan dalam kurikulum. Kegiatan ekstra- kurikuler merupakan perangkat operasional (supplement dan complements) kurikulum, yang perlu disusun dan dituangkan dalam rencana kerja tahunan/kalender pendidikan satuan pendidikan.Kegiatan ekstrakurikuler dilaksanakan agar peserta didik dapat mengembangkan kepribadian, minat, dan kemampuannya di luar bidang akademik.

Hidayat dan Setia (2012: 18) menjelaskan kegiatan ekstrakurikuler adalah kegiatan pendidikan diluar mata pelajaran untuk membantu pengembangan siswa sesuai dengan kebutuhan, potensi, bakat, dan minat mereka melalui kegiatan yang secara khusus diselenggarakan oleh pendidik atau tenaga kependidikan yang berkemampuan dan berkewenangan di sekolah.Senada dengan Rohadi, (2017) kegiatan ekstra-kurikuler adalah kegiatan pendidikan yang dilakukan peserta didik di luar jam belajar kurikulum standar. Kegiatan ekstrakurikuler ditujukan agar peserta didik dapat mengembangkan kepribadian, minat, dan kemampuannya di berbagai bidang di luar bidang akademik.

Dalam Permendikbud pasal 1 Nomor 62 tahun 2014 menjelaskan 
bahwa, Kegiatan Ekstrakurikuler adalah kegiatan kurikuler yang dilakukan oleh peserta didik di luar jam belajar kegiatan intrakurikuler dan kegiatan kokurikuler, di bawah bimbingan dan pengawasan satuan pendidikan sekolah dasar dan menengah. Permendikbud nomor 63 tahun 2014 juga menjelaskan bahwa, ekstrakurikuler adalah kegiatan pendidikan yang dilakukan peserta didik di luar jam belajar kurikulum standar, dan ditujukan agar peserta didik dapat mengembangkan kepribadian, minat dan kemampuannya diberbagai bidang di luar bidang akademik.

Berdasarkan uraian di atas, dapat disimpulkan bahwa kegiatan ekstrakurikuler yang dilaksanakan pada satuan pendidikan merupakan kegiatan yang dilakukan oleh peserta didik diluar jam belajar kurikulum standar untuk mendukungkegiatan intra kurikuler. Apaun tujuankegiatan ekstra-kurikuler mengembangkan kepribadian, bakat, minat, dan kemampuan peserta didik dibawah bimbingan dan pengawasan guru pada sekolah tersebut. Pendapat ini didukung oleh Peraturan menteri pendidikan nasional (Permendiknas) Nomor 39 Tahun 2008 pasal (1) ayat
(1) tentan tujuan dan manfaat kegiatan ekstrakurikuler adalah:

Mengembangkan potensi siswa secara optimal dan terpadu yang meliputi bakat, minat, dan kreativitas, 2) Memantapkan kepribadian siswa untuk mewujudkan ketahanan sekolah sebagai lingkungan pendidikan sehingga terhindar dari usaha dan pengaruh negatif dan bertentangan dengan tujuan pendidikan, 3)Mengaktualisasikan potensi siswa dalam pencapaian prestasi unggulan sesuai bakat dan minat, 4)Menyiapkan siswa agar menjadi warga masyarakat yang berakhlak mulia, demokratis, menghormati hak-hak asasi manusia dalam rangka mewujudkan masyarakat madani (civil society)

Sedangkan berkaitan dengan kegiatan kepramukaan, sekolah yang melaksanakan kurikulum 2013, pendidikan kepramukaan merupakan kegiatan ekstra-kurikuler wajib. Dimana kegiatan ekstra-kurikuler kepramukaan wajib diikuti oleh seluruh peserta didik, terkecuali peserta didik dengan kondisi tertentu yang tidak memungkinkannya untuk mengikuti kegiatan ekstrakurikuler tersebut. Sebab proses pembelajaran kurikulum 2013 merupakan perpaduan kegiatan 
intrakurikuler dan ekstrakurikuler.Hal ini sesuai dengan Peraturan Menteri Pendidikan dan Kebudayaan (Permendikbud) Nomor 81A Tahun 2013 tentang Implementasi Kurikulum menegaskan bahwa pelaksanaan Kurikulum 2013 didukung dengan ekstrakurikuler untuk mendukung Kompetensi Inti Sikap Spiritual (KI 1), Sikap Sosial (KI 2), dan Keterampilan (K3) sebagai semangat dari kurikulum 2013 tersebut.

\section{PENINGKATAN MUTU SEKOLAH}

Mutu (kualitas) pendidikan di sekolah merupakan hasil dari suatu proses pendidikan, termasuk proses kurikulum baik intra maupun ekstrakurikuler. Apabila semua proses berjalan baik, efektif dan efisien, maka terbuka peluang memperoleh hasil pendidikan yang bermutu. Variabel mutu (kualitas) pendidikan dapat dipandang sebagai variabel terikat yang dipengaruhi banyak faktor seperti kepemimpinan, iklim organisasi, kualifikasi guru, anggaran, kecukupan fasilitas belajar dan hubungan masyarakat serta kegiatan ekstrakurikuler.

Dengan demikian pengertian mutu adalah sebuah proses terstruktur untuk memperbaiki keluaran yang dihasilkan berdasarkan standar mutu yang ditetapkan dalam keseluruhan proses kerja.Sedangkan mutu sekolah adalah mutu dalam pendidikan di sekoalah yang membedakan antara kesuksesan dan kegagalan.

Menurut Edward Salis (2006: 3031) sumber mutu pendidikan :

"ada banyak sumber mutu dalam pendidikan di sekolah , misalnya sarana gedung yang bagus, guru yang terkemuka, nilai moral yang tinggi, hasil ujian yang memuaskan, spesialisasi atau kejuruan, dorongan orang tua, bisnis dan komunitas lokal, sumberdaya yang melimpah, aplikasi teknologi mutakhir, kepemimpinan yang baik dan efektif, perhatian terhadap pelajar an anak didik, kurikulum yeng memadai, atau juga kombinasi dari faktor-faktor tersebut".

Mintarsih Danumihardja (2004:6) dikutip dari Heyman dan Loxley (1989), menyatakan bahwa faktor guru, waktu belajar, manajemen sekolah, sarana fisik dan biaya pendidikan memberikan kontribusi yang berarti terhadap prestasi belajar siswa. Hasil Penelitian tersebut menunjukkan bahwa ketersediaan dana untuk penyelenggaraan proses pendidikan di sekolah menjadi salah satu faktor penting untuk dapat memenuhi kualitas 
dan prestasi belajar, dimana kualitas dan prestasi belajar pada dasarnya mengagambarkan kualitas pendidikan.

Sementara itu Nanang Fatah (2000: 90) mengemukakan upaya peningkatan mutu dan perluasan pendidikan di sekolah membutuhkan sekurang-kurangnya tiga faktor utama yaitu (1) Kecukupan sumber-sumber pendidikan dalam arti kualitas tenaga kependidikan, biaya dan sarana belajar; (2) Mutu proses belajar mengajar yang mendorong siswa belajar efektif; dan (3) Mutu keluaran dalam bentuk pengetahuan, sikap ketrampilan, dan nilai-nilai. Jadi kecukupan sumber, mutu proses belajar mengajar, dan mutu keluaran akan dapat terpenuhi jika dukungan biaya yang dibutuhkan dan tenaga professional kependidikan dapat disediakan di sekolah, dan semua ini tentu saja memerlukan sumber daya pendidikan termasuk biaya.

Berdasarkan uraian di atas, maka mutu sekolah adalah sekolah yang mendapat dukungan dari masyarakat, menciptakan lingkungan kondusif bagi peserta didik, pendidik dan orang tua, sekolah mampu melaksanakan kerjama dengan pemerintah, komite sekolah dan pemuka bisnis guna mempersiapkan para peserta didik sebagai sumber daya mampu mengantisipasi berbagai tantangan akademik dan tantangan kerja. Untuk memperoleh sekolah yang bermutu harus memiliki rencana program pendidikan yang bermutu yang merefleksikan kondisi lingkungan sekolah.

\section{METODE}

Penelitian ini mengunakan penelitian deskriptif dengan pendekatan kualitatif yang bertujuan untuk memahami fenomena serta mendeskripsikan tentang apa yang dialami oleh subyek penelitian dengan menggambarkan gejala/prilaku secara menyeluruh sesuai kontekspenelitian.Kehadiran peneliti merupakan instrumen kunciuntuk dalam penelitian.Lokasi penelitian ini di MAN 2 Ruteng-Flores NTT. Penelitian dilaksanakanpadatanggal 01 Pebruari sampai tanggal 5 Mei 2018. Sumber data dalam penelitian kepala sekolah dan guru MAN (orang), kegiatankegiatan di MAN (aktifitas), dan simbolsimbol yang ada di sekolah (paper).

Untuk mengungkap permasalahan secara holistikdalam penelitian ini, peneliti menggunakan teknik pengumpulan data yaitu: teknik 
observasi partisipatif (participant observation) yang taraf partisipasinya menyesuaikan dengan konteks, wawancara mendalam (in-depth interview) dan dokumentasi (documentation). Instrumen utama dalam penelitian adalah peneliti sendiri didukung dengan pedoman wawancara dan pedoman observasi. Sedangkan analisis data secara deskriptif model interaktif yang diadopsi dari Mile dan huberman (1992: 18) dalam Arifin, (2006: 97) yaitu: pengumpulan data, penyajian dan penarikan kesimpulan/ verifikasi data. Sedangkan untuk mengetahui keabsahan data menggunakantriangulasi sumber dengan menggunakan beberapa informan (Kepala sekolah, guru, Komite sekolah/orangtua, staf) dengan membandingkan antara informan yang satu dengan yang lainnya guna memperoleh hasil yang maksimal (Moleong, 2002: 178)

\section{HASIL}

Peran manajer Kepala sekolah MAN 2 Manggarai Dalam Kegiatan Ekstrakuriuler Kepramukaan Kurikulum 2013.

Peran sebagai manajer kepala MAN 2 Manggarai Ruteng sudah berjalan dengan baik.Proses perencanaan (P) kegiatan ekstrakurikuler diawali: (1) pendataan jenis kegiatan ekstra-kurikuler bersama semua guru, kemudian wakil kepala sekolah yang menangani kurikulum dan waka kurikulum bidang kesiswaan, (2) mensosialisasi kepada seluruh siswa berkaitandengan jenis kegiatan ekstra-kurikuler wajib kepramukaan.Proses perencanaan kegiatan ekstra-kurikuler wajib kepramukaan menjadi komitmen kepala sekolah MAN, guru dan staf. Kepala sekolah MAN dan semua guru dan staf menunjukan kepribadian yangberkontribusi melaksanakan program ekstra-kurikuler dengan penuh tanggung jawabnya, terbuka,dan percaya diri bahwa kegiatan ekstrakurikuler wajib kepramukaan dapat meningkatkan kualitas pendidikan yang di MAN 2 Manggarai Ruteng.

Kompetensi Sosial, Kepala sekolah MAN 2 Manggarai Rutengdapat dilihat melalui:(1) selalu menjalin komunikasi dan kerjasama dengan pihak guru, staf, komite sekolah, dan pemerintah kabupaten, (2)selalu berpartisipasi dalam kegiatan sosial, di sekolah maupun dilingkungan sekolah, (3) sebagai manajer,kepala MAN 2 bekerja sama dengan guru dan 
staf, sehingga penyusunan perencanaan pengembanagn sekolah jangka pendek, menengah, dan jangka panjang dapat terwujudkan dalam bentuk dokumen sekolah MAN. Semua dilaksanakan dan di organisasikan dalam program kerja tahunan sekolah serta mampu menjabar secara jelas (tujuan, program kegiatan dan waktu pelaksanaan) termasuk kegiatan ekstra-kurikuler sebagaimana tuntutan Kurikulum 2013.

Sedangkan dalam prinsip pengorganisasian MAN 2 Manggarai hasil wawancra peneliti dengan semua informen yatu: 1) terbaginya semua tugas kepada semuaguru sesuai kompetensi guru.Tugas masing-masing guru dibagi dalam sub-sub atau komponen-komponen organisasi sekolah MAN, 2)semua kegiatan ekstra-kurikuler selalu berkoordinasi dan dikomunikasikan.

Proses pelaksanaan Kegiatan Ekstra-kurikuler kepramukaan di MAN 2 Manggarai Ruteng berdasarkan pengamatan dan wawancara dengan semua nara sumber adalah: 1) pelaksanaan kegiatan ekstra-kurikuler kepramukaan diatur dan disusun secara tertulis, 2) pelaksanaan kegiatan ekstra-kurikuler dimulai dari awal tahun pelajaran, 3)pelaksanaansetelah jam pelajaran intra-kurikuler berakhir, 4) Waktu, tempat dan hari pelaksanaan kegiatan diatur oleh masing-masingguru yang mengampuh kegiatan tersebut. Pihak yang terlibat dalam proses pelaksanaan kegiatan ekstra-kurikuler Kepramukaan di MAN 2 Manggarai adalah kepala sekolah MAN 2 Manggarai, guru dan Komite. Pihak sekolah menerapkan prosedur tertentu untuk mengetahui atau mengukur keberhasilan kegiatan ekstrakurikuler yang dilakukan oleh siswa. Pelaksanaan kegiatan ekstrakurikuler di MAN 2 Manggarai siswa harus mendapat nilai 70, tingkat kehadiran $70 \%$. Dengan adanya proses penggerakan atau pelaksanaan terhadap kegiatan ekstrakurikuler di MAN 2 Manggarai, setiap tahun selama mengikuti perlombaan baik ditingkat kabupaten, propinsi maupun nasional selalu meraih juara. Hal ini terlihat di ruangan kepala MAN 2 terpasang piala dan berbagaimacam sertifikat penghargaan (Hasil studi doc, observasi, dan wawancara)

Proses pengawasan kegiatan Ekstra-kurikuler kepramukaan di MAN 2 Manggarai Ruteng yaitu dilakukan 
oleh kepala sekolah dan kegiatan pengawasan tersebut berlangsung pada saat latihan kegiatan ekstrakurikuler berlangsung serta pada saat ada kegiatan kompetisi kegiatan ekstra-kurikuler. Tujuan dari proses pengawasan kegiatan ekstrakurikuler di MAN 2 Manggarai yaitu agar kegiatan ekstrakurikuler wajib maupun pilihan yang dilakukan oleh siswa dapat terlaksana dan terkendali dengan baik, serta jika ada kekurangan atau penyimpangan, maka akan segera perbaiki dan dicari solusinya. Selama ini semua kegiatan pengawasan berjalan secara fleksibel.

Prinsip pengawasan fleksibel, yang menekakan hasi kegiatan ekstrakurikuler dapat berjalan dan berkembang lebih baik sesuai spirit kurikulum 2013.Dengan adanya pengawasan yang dilakukan oleh pihak Kepala sekolah MAN dapat mengetahui apakah pelaksanaan terhadap kegiatan ekstra-kurikuler telah berjalan sesuai dengan aturan yang berlaku dan tidak ada penyimpangan. Sehingga apabila terjadi penyimpangan terhadap kegiatan ekstra-kurikuler dapat segera diperbaiki guna meningkatkan mutu dan mengembangkan kegiatan ekstra- kurikuler dimasa yang akan datang (kesimpulan semua wawancara informen)

Upaya Kepala Sekolah Mengelolah Ekstra-kurikuler Keparamukaan Dalam Meningkakan Mutu Sekolah MAN 2, kepala MAN 2 selalu berusaha memperbaiki dan memperbaharui model-model pembelajaran ekstra-kurikuler, yaitu: (a) guru atau staf di MAN mendatangkan para pakar pendidikan untuk mengadakan pelatihan sesuai bidang masing-masing, (b) guru-guru dikirim untuk mengikuti pendidikan dan latihan (diklat) di luar daerah, baik di tingkat kabupaten, propinsi maupun tingkat nasional, (c) Mendatangkan guru di luar sekolah MAN untuk mengajarkan pendidikan ekstrakurikuler bagi siswa, (d) aturan sekolah diperketak seperti tata tertib sekolah untuk semua guru, staf dan siswa, (e) selalu membangun hubungan baik dengan masyarakat. (Kepala MAN 2 Manggarai)

Uraian di atas dapat dimaknai kegiatan ekstrakurikuler wajib kepramukaan kurikulum 2013 dan kegiatan ekstrakurikuler pilihan tidak dapat berjalan dengan lancer tanpa adanya inovasi oleh kepala sekolah 
MAN. Jadi hubungan yang baik, sarana prasarana, dan guru berkompeten di sekolah merupakan "kunci" berkembang dan berkulitasnya kegiatan ekstra-kurikuler kepramukaan di MAN 2 Manggarai Ruteng.

\section{PEMBAHASAN}

Peran manajer kepala sekolah MAN 2 Manggaraitelah dilaksanakan dengan baik. Terutama dalam mengelola ekstra-kurikuler wajib kepramukaan dalam kurikulum 2013. Terdapat beberapa unsur peran kepala sekolah yang sesuai dengan teori Goston (1976) dalam Kats \& Dill (1984), yaitu: (1) Ketrampilan konseptual,artinya

kemampuan/ketrampilan yang diperlukan seorang pemimpin untuk memahami dan mengoprasikan organisasi. (2) Ketrampilan dalam hubungan sosial, ketrampilan untuk bekerja sama, memotivasi dan memimpin organisasi. (3) Ketrampilan teknik artinya ketrampilan dalam menggunakan pengetahuan, metode, strategi, teknik tertentu dalam organisasi.

Ketiga unsur peran kepala sekolah di atas kepala sekolah MAN 2 Manggarai menyadari bahwa salah satu dari unsur peran kepala sekolah tidak fungsikan atau tidak digunakan, maka mutu input, proses dan out put sekolah MAN 2 tidak terwujud sesuai visi misi sekolah.

Dalam proses perencanaan $(P)$ seluruh kegiatan ekstrakurikuler kepramukaan di MAN 2 Manggarai, kepala sekolah MAN mampu menunjukan kepribadian (prilaku) yang menyenangkan dan komunikasi yang dapat diterima oleh semua warga sekolah. Proses perencanaan kegiatan ektrakurikuler wajib di MAN 2 Manggarai merupakan tanggung jawab Kepala Sekolahdibantu oleh wakil kepala sekolah bagian kurikulum dan bagian kesiswaan dalam kegiatan ekstrakurikuler. Dalam menetapkan kegiatan ekstrakurikuler pramuka menjadi kegiatan wajib bagi semua siswa.dan PMR serta Drumben sebagai kegiatan ekstrakurikuler pilihan bagisiswa. Kegiatan ekstra-kurikuler wajib kepramukaan tersebut dilaksanakan diluar jam sekolah.

Tahapan dalam proses perencanaan kegiatan ekstrakurikuler,diawali dengan: menginventarisir jumlah kegiatan ekstra-kurikuler, (2) mensosialisasi jenis ekstrakurikuler kepada seluruh siswa, (3) memperkenalkan pembina 
kegiatan ekstra-kurikuler kepada semua siswa oleh siswa yang senior, (4) pemilihan anggota kegiatan ekstrakurikuler setiap kelas. Selain itu pihak sekolah juga membuat program kerja kegiatan ekstrakurikuler untuk jangka waktu satu tahun. Jenis kegiatan ekstra-kurikuler atau yang disebut pengembangan diri di MAN 2 Manggarai. Kegiatan ekstrakurikuler tersebut adalah salah satu syarat dalam kenaikan kelas siswa. Siswa yang mengikuti kegiatan ekstrakurikuler tersebut harus mendapat nilai minimal 70 untuk naik kelas. Oleh sebab itu, seluruh siswa antusias dan berpartisipasi aktif dalam kegiatan ekstrakurikuler wajib kepramukaan di sekolah.

Proses

pengorganisasian

kegiatan ekstrakurikuler di MAN 2 Manggarai terbagi 2, yaitu: kegiatan ekstrakurikuler wajib kepramukaan dan kegiataan ekstrakurikuler pilihan (PMR dan Drumben). Pengorganisasian kegiatan ekstrakurikuler sangat penting, karena dapat memberi menentukan kerangka pelaksanaan dari rencana-rencana yang telah ditetapkan. Pengorganisasian merupakan pengelompokan aktivitas kegiatan ekstrakurikuler sehingga dapat mencapai tujuan yang telah ditetapkan. Proses pengorganisasian terhadap kegiatan ekstrakurikuler wajib kepramukaan dan kegiataan ekstrakurikuler pilihan (PMR dan Drumben) bagi siswa untuk mempermudah koordinasi oleh kepala sekolah dan pihak-pihak yang terlibat dalam kegiatan ekstrakurikuler tersebut. Pengkoordinasian oleh pihak kepala sekolah terhadap kegiatan ekstrakurikuler, sebatas membagi tugas kepada guru-guru yang terlibat dalam menangani atau mengelola kegiatan ekstrakurikuler wajib kepramukaan dan kegiataan ekstrakurikuler pilihan (PMR dan Drumben) bagi siswa. Proses pengaturan atau pengorganisasian sangat diperlukan dalam suatu kelompok organisasi kesiswaan, hal ini dibuktikan dengan pembagian tugas dan tanggung jawab setiap anggota kegiatan ekstrakurikuler guna memperlancar dalam implementasi kegiatan ekstrakurikuler secara lebih efektif dan efisien.

Hal tersebut di atas sesuai teori Barnard ( Fattah, 2004) organisasi mengandung tiga elemen yaitu, 1) kemampuan untuk bekerja sama, 2) tujuan yang ingin dicapai, 
komunikasi. Pengorganisasiansebagai proses membagi kerja dalam tugastugas yang lebih kecil, membebankan tugas-tugas itu kepada orang yang sesuai dengan kemampuannya, dan mengalokasikan sumber daya,

serta mengkoordinasikannya dalam rangka efektivitas pencapaian tujuan organisasi. Proses pengorganisasian yang dilakukan sekolah MAN 2 Manggarai sudah berjalan optimal. Semua itu dapat berjalan dengan lancar atas bantuan dari guru, staf dan komite sekolah sesuai tugas dan fungsi masing-masing. Kepala sekolah, Wakil Kepala sekolah bagian kurikulum, wakil kepala sekolah kesiswaan, wakil kepala sekolah bagian sarana prasarana dan wakil kepala sekolah bidang hubungan masyarakat (Humas), staf, pembina atau pelatih kegiatan ekstrakurikuler dan siswa yang mengikuti kegiatn ekstrakurikuler tersebut. Pihak sekolah dengan tegas melakukan pengkodinasian terhadap kegiatan ekstrakurikuler di sekolah sehingga mendapatkan hasil sesuai dengan tujuan yang telah dalan Visi/ Misi MAN 2 Manggarai. Semua komponen dalam pengorganisasian selalu bekerjasama guna peningkatan mutu sekolah MAN.

Hal tersebut sesuai dengan teori Kartini Kartono (1983 : 150 -152), yaitu: " ...(a) Kemauan untuk memikul tanggung jawab artinya seorang yang diserahi sebagai pemimpin berani memikul tanggungjawab bagi setiap tingkah lakunya sehubungan dengan tugas-tugas dan peranan yang harus dilakukannya ( keleluasaannya, kewibawaannya, mendapatkan status posisi penghargaan tertentu, motivasi pribadi, mampu membawa pengikutnya pada pencapaian tujuan organisasi), (b) Kemampuan untuk menjadi perseptif, dimaksudkan bahwa persepsi merupakan kemampuan untuk melihat dan menanggapi realita yang benar benar nyata, artinya seorang pemimpin harus memiliki daya persepsi terhadap semua situasi organisasi yang dibawahinya dengan cara mengamati segi segi kekuatan dan kelemahan (strenghteness and weakness), kemudian mampu mengadakan intrspeksi melihat kedalam diri sendiri ia mengenali segi segi kekuatan dan kelemahan sendiri dikaitkan dengan beratnya tugas tugas dan besarnya tanggungjawab yang harus dipikulnya, (c) Kemampuan 
untuk menanggapi secara obyektif. Obyektifitas merupakan kemampuan untuk melihat masalah-masalah secara rasional, impersonal dan tanpa prasangka yang merupakan kelanjutan dengan cara mengabaikan faktor-faktor pribadi dan emosional yang mengakibatkan gagalnya harapan. Obyektivitas merupakan juga unsur penting dalam pengambilan keputusan. Pengambilan keputusan yang bijaksana dan melakukan satu seni tindakan yang konsisten, (d) Kemampuan untuk menetapkan prioritas secara tepat, hal ini dimaksudkan bahwa kemampuan, kemahiran, pandai memilah dan memilih mana bagian yang penting dan harus dilakukan dan dimana bagian yang kurang penting sehingga dapat ditunda pelaksanaannya dalam artian bahwa kemampuan memilih keputusan dari kesekian banyak alternative dengan tepat, (e) Kemampuan untuk berkomunikasi dimaksudkan adalah kemampuan untuk memberikan informasi dengan cermat, cepat dan jelas dan juga kemampuan menerima informasi dengan kepekaan tinggi, kemampuan mengatakan bahasa policy apabila terjadi komunikasi tidak lancar akan menimbulkan perasaan terisolasi dan dipisahkan dari organisasi akibat dari kecemasan, ketegangan bathin, individu menjadi terdampar, peka (oversensitive) dan mudah berkonflik dengan orang orang disekitarnya, disebabkan juga oleh kesulitan dan kesalahfahaman akibat dari tidak dapat dipecahkan dan didiskusikan permasalahannya yang akhirnya anak buah atau pengikutnya menjadi frustasi, menambah beban psikologis terhadap dirinya sebagai pemimpin..."

Proses penggerakan atau pelaksanaan kegiatan ekstrakurikuler wajib maupun pilihan di MAN 2 Manggarai sudah berjalan dengan baik, namun perlu adanya perbaikan,mengingat di MAN 2 Manggarai banyak unit kegiatan ekstrakurikuler,Masih kurangnya sarana prasarana penunjang. Pelaksanaan kegiatan ekstra-kurikuler di MAN 2 Manggarai dilaksanakan di halaman sekolah. Hal ini berakibat kurangoptimal dalam kegiatan karena karena halaman sekolah sempit. Selain itu jadwal kegiatan ekstrakurikuler tidak konsisten sesuai jadwal.Dalam teori yang dijelaskan Husein (2009:3) menyatakan pelaksanaan merupakan implementasi dari perencanaan yang 
telah ditetapkan dengan melakukan tahapan pekerjaan yang sesungguhnya secara fisik maupun non fisik sehingga produk akhir sesuai sasaran dan tujuan yang ditetapkan. Dalam pelaksanaan kegiatan ekstrakurikuler di MAN 2 Manggarai ini sangat mendukung peningkatan kualitas sekolah dimata masyarakat. Hal ini juga terlihat dari partisipasi dan antusias para siswa dalam mengikuti kegiatan ekstrakurikuler yang diadakan oleh pihak sekolah. MenurutSoewadji Lazaruth (1992:21-22) mengatakan untuk meningkatkan mutu sekolah, kepala sekolah bertugas mengembangkan dan memperbaiki sumber daya sekolah.

Proses pengawasan kegiatan ekstra-kurikuler wajib maupun pilihan di MAN 2 Manggarai dilakukan oleh kepala sekolah MAN. Kecuali kalau kepala sekolah berhalangan, kegiatan ekstra-kurikuler di awasi oleh Pembina kegiatan ekstra-kurikuler dibawah pengarahan dari wakil kepala sekolah bagian kesiswaaan. Pengawasan tersebut dilakukan pada saat kegiatan ekstra-kurikuler berlangsung yaitu setelah jam pelajaran berakhir.

Menurut teori Murdick (Fattah, 2004) pengawasan merupakan proses dasar yang esensial tetap diperlukan bagaimana pun rumit dan luasnya suatu organisasi. Pengawasan harus dikaitkan dengan tujuan, dan kriteria yang dipergunakan dalam sistem pendidikan, yaitu relevansi, efektivitas, efisiensi dan produktivitas. Pengawasan hendaknya disesuaikan dengan sifat dan kebutuhan organisasi, tindakan dan perbaikan, artinya tidak hanya mengungkap penyimpangan dari standar, tetapi penyediaan alternatif perbaikan dan menentukan tindakan perbaikan.

Untuk mengoptimalisasikan proses pengawasan terhadap kegiatan ekstrakurikuler tersebut, pihak sekolah menyerahkan sepenuhnya kepada pembina masing-masing kegiatan ekstra-kurikuler. Kegiatan ekstra-kurikuler dapat berjalan dengan lancar, apabila :(1) semua kebutuhan yang diperlukan oleh masing-masing kegiatan ekstrakurikuler disediakan, (2) penilaian atau evaluasi dan pengontrolan tugas,(3) menggunakan standar yangsudah ditetapkan dalam perencanaan, (4) Setiap prestasi kerja dinilai dan diukur untuk mengetahui kekurangan dan penyimpangan untuk segera dilakukan koreksi revisi. 
Berdasarkan uraian di atas, maka pelaksanaan pengawasan di MAN 2 Manggarai sudah sesuai dengan teori Craig (1987) kemampuan kepala sekolah dapat berhasil melaksanakan tugasnya sebagaimana tugas seorang pengawas dan berfungsi sebagai seorang supervisor adalah:

Membuat perencanaan kerja, (2)

Memecahkan masalah,

Mengendalikan pekerjaan,

Mengumpulkan dan memanfaatkan masukan umpan balik (performance feedback),

(5) Melatih dan membimbing,

(6) Memotivasi,

Mengatur waktu, (8) Komunikasi lisan maupun tulis, (9) Mengembangkan kemampuan diri, (10) Mewakili lembaga, (11). Menghadiri dan menyelenggarakan rapat-rapat (Yusuf A. Hasan dan Muhammad Idrus, 2003: 9)

Upaya Kepala Sekolah Mengelolah Ekstrakurikuler KeparamukaanDalam Meningkatkatkan Mutu Sekolah. Semua guru di MAN 2 Manggarai selalu mengembangkan kemampuan mengajar dengan mendatangkan pakar untuk melaksanakan pendidikan dan latihan (diklat). Bahkan guru-guru secara bergilir mengikuti pendidikan dan latihan (diklat) di kabupaten, propinsi bahwa sampai ke tingkat nasional.

Menurut Pherson, Crowson dan Pinter, (1986), menjelaskan: “... sekolah sangat tergantung pada tenaga guru yang professional dengan memilki tingkat berfikir yang abstrak, dan memilki komitmen yang tinggi terhadap tugasnya, disamping itu kepala sekolah hendaknya mengetahui kinerja guru yang professional ,beranii mengahadapi tantangan, tanggung jawaban terhadap kerja, selalu mau mengembangkan diri, selalu mengupayakan peningkatan kinerja penyelenggara pendidikan.

Senada dengan Miftah Thoha, (2004: 15), diperlukan kemampuan kepala sekolah dalam berkomunikasi, daya kreasi serta inisiatif yang tinggi dan mampu mendorong semangat dari para guru/karyawannya, dengan beberapa prinsip : a) Memperlakukan para pegawai dengan sebaik-baiknya, b) Mendorong pertumbuhan dan pengembangan bakat dan kemampuan para pegawai tanpa menekan daya kreasinya, c) Menanamkan semangat para pegawai agar mau terus berusaha meningkatkan bakat dan kemampuannya; d) Menghargai setiap karya yang baik dan sempurna yang 
dihasilkan para pegawai;

Menguasahakan adanya keadilan dan bersikap bijaksana kepada setiap pegawai tanpa pilih kasih; f) Memberikan kesempatan yang tepat bagi pengembangan pegawainya, baik kesempatan belajar maupun biaya yang cukup untuk tujuan tersebut; g) memberikan motivasi untuk dapat mengembangkan potensi yang dimiliki para pegawai melalui ide, gagasan dan hasil karyanya.

Dalam melaksanakan tugas sebagai manajer, perlunya kerjasama tim, menjalin hubungan baik dengan masyarakat,menemukan gagasangagasan/ide-ide baru yang dapat diterapkan di sekolah yang dipimpinnya. Sesuai teori Enco Mulyasa (2003: 118-119) menyatakan bahwa kepala sekolah sebagai inovator akan tercermin dari cara-caranya dalam melakukan pekerjaan secara (1) konstruktif yaitu membina setiap tenaga kependidikan untuk dapat berkembang secara optimal dalam melaksanakan tugas yang diembannya, (2) kreatif yaitu berusaha mencari gagasan dan cara-cara baru dalam melaksanakan tugasnya, (3) delegatif yaitu berusaha mendelegasikan tugas kepada tenaga kependidikan sesuai dengan deskripsi tugas, jabatan serta kemampuan masing-masing, (4) integratif yaitu berusaha mengintegrasikan semua kegiatan sehingga dapat menghasilkan sinergi untuk mencapai tujuan sekolah secara efektif, efisien dan produktif, (5) rasional dan objektif yaitu berusaha bertindak dengan mempertimbangkan rasio dan obektif, (6) pragmatis yaitu berusaha menetapkan kegiatan atau target berdasarkan kondisi dan kemampuan nyata yang dimiliki oleh setiap tenaga kependidikan, serta kemampuan sekolah, (7) keteladanan yaitu kepala sekolah harus menjadi teladan dan contoh yang baik bagi bawahannya, (8) disiplin, serta (9) adaptabel dan fleksibel yaitu mampu beradaptasi dan fleksibel terhadap sesuatu yang inovatif, serta berusaha menciptakan situasi kerja yang menyenangkan dan memudahkan bagi setip tenaga kependidikan dalam melaksanakan tugas dan kewajibannya Kegiatan ekstrakurikuler wajib kepramukaan dan pilihan di MAN 2 Manggarai sesuai visi tentang perkembangan, tantangan, kebutuhan, masalah, dan peluang pada masa yang akan datang. Kepala MAN 2 Manggarai mempunyai rencana kerja yang jelas, 
yaitu perbaikan peringkat hasil UASBN dan UANdi sekolah.Tanggung jawab perbaikan mutu sekolah. Adapun prinsip-prinsip yang dipegang dalam menerapkan program mutu sekolah MAN 2 Manggarai yaitu : a) professional pendidik dalam memperbaiki metode pembelajaran, b) pengembangan atau penerapan cara atau proses baru untuk memperbaiki proses pembelajaran yang ada, c) menanamkan norma dan kepercayaan lama harus diubah. Sekolah harus belajar bekerja sama dengan sumbersumber yang terbatas, d) komitmen pada perubahan, semua guru dan staf sekolah telah memiliki komitmen pada perubahan, memperbaiki efisiensi, produktivitas dan kualitas layanan.

Uraian di atas sesuai dengan teori Sukmadinata, (2006: 8-9) bahwa rencana menjadi pegangan dalam proses pelaksanaan program mutu. Rencana harus selalu sesuai dengan perubahan dan perkembangan zaman. Tidak ada program mutu yang terhenti (stagna) dan tidak ada dua program yang identik karena program mutu selalu berdasarkan dan sesuai dengan kondisi lingkungan. Program mutu merefleksikan lingkungan pendidikan dimana pun ia berada.
Mutu sekolah bukan sesuatu yang terjadi dengan sendirinya, Namun melalui proses yang efektif dan efisien yang saling terkait oleh banyak faktor seperti kepemimpinan, iklim organisasi, kualifikasi guru, anggaran, kecukupan fasilitas belajar. Teori Edward Salis (2006: 30-31), ada banyak sumber mutu dalam pendidikan, misalnya sarana gedung yang bagus, guru yang terkemuka, nilai moral yang tinggi, hasil ujian yang memuaskan, spesialisasi atau kejuruan, dorongan orang tua, bisnis dan komunitas lokal, sumberdaya yang melimpah, aplikasi teknologi mutakhir, kepemimpinan yang baik dan efektif, perhatian terhadap pelajar an anak didik, kurikulum yeng memadai, atau juga kombinasi dari faktor-faktor tersebut"

\section{KESIMPULAN}

Berdasarkan fokus penelitian, paparan data dan temuan serta pembahasan, maka penelitian terumuskan dalam 5 kesimpulan, sebagai berikut:

1. Peran manajer Kepala Sekolah MAN 2 Manggarai dalam mengelola kegiatan ekstrakuriuler kurikulum 2013, mulai dari proses perencanaan, proses pengorganisasian, 
proses pelaksanaan, dan proses evaluasi sangan baik. Hal ini di tunjukan dengan kepribadian (prilaku) dan keterampilan kepala sekolah MAN dalam memimpin sekolah MAN yang selalu diterima oleh seluruh warga sekolah

2. Untuk meningkatkan mutu sekolah perlunya komitmen tinggi terhadap perubahan zaman, lebih intens membangun hubungan dengan masyarakat melalui Komite sekolah.

3. Mengembangkan kemampuan mengajar yang professional dengan memilki tingkat berfikir yang abstrak, dan memilki komitmen yang tinggi terhadap tugasnya.

4. Tanggung jawaban terhadap kerja, selalu mau mengembangkan diri, selalu mengupayakan peningkatan kinerja

5. Membangun kerja sama internal sekolah dan eksternal baik dengan pemerintah daerah maupun masyarakat atau komite sekolah

\section{DAFTAR PUSTAKA}

Agus. 2010.Perencanaan Dan pengembangan Sumberdaya Manusia. Alfabeta: Bandung

Craig,.1987.Human Resource Managament in Education (Manajemen Sumber Daya Manusia dalam Pendidikan. Jakarta : Q-Media

Edward, Salis. 2006. Prinsip Dasar Manajemen. Edisi 2. Yogyakarta: BPFE.

E. Mulyasa. 2003. Kurikulum Pembelajaran. Bandung: PT Remaja Rosda Karya

Fatah,Nanang. 2000, Landasan Manajemen Pendidikan. Bandung: PT RemajaRosdakarya Offset 2004.Pengendalian Mutu Pendidikan Sekolah Menengah. Bandung: PT Refika Aditama

Hani, Handoko,T. 1995. Manajemen. Yogyakarta: BPFE

Hidayat, 2012. Kepemimpinan dan Supervisi Pendidikan. Jakarta: Bina Aksara

Husein. 2009. Manajemen Proyek. Yogyakarta: Andi Offset.

Kats \&Dill . 1984. Quality Management: Introduction to Total Quality Management for Production, Processing, and Service, New Jersey:Prentice Hall

Lazaruth ,S., 1992.Pengelolaan Interaksi Belajar Mengajar Intrakurikuler, Kokurikuler, dan Ekstrakurikuler. Jakarta: IKIPJakarta

Miftah, Toha. 1995. Kepemimpinan dalam Manajemen. Jakarta: Raja Grafindo Persada. , 2004.Perilaku Organisasi Konsep Dasar dan Aplikasinya. Jakarta: Raja Grafindo Persada Mile dan huberman. 1992. Metodologi Penelitian Kualitatif. Bandung: PT RemajaRosdakarya. 
Danumihardja, Mintarsih. 2004. Buku Ajar Manajemen Layanan Khusus. Malang:

UniversitasNegeri Malang.

Moleong. 2002. Metodologi Penelitian Kualitatif. Bandung: PT RemajaRosda karya.
Undang-undang No. 12 tahun 2010 Tentang Gerakan Pramuka: Jakarta

Undang-Undang Republik Indonesia Nomor 14 Tahun 2005 Tentang Guru Dan Dosen. Jakarta: Balai Pustaka

Siagian., 2002. Manajemen Sumber Daya Manusia. Jakarta: Bumi Aksara.

Sugiyono.,2005.Metode Penelitian Kuantitatif, Kualitatif dan $R \& B$.Bandung: Alfabeta

Suharsimi Arikunto., 2005.Metode Penelitian Pendidikan. Bandung. PTRemaja Rosdakarya Offset.

Wahjosumidjo., 2005.Kepemimpinan Kepala Sekolah Tinjauan Teoritik dan Permasalahannya. Jakarta: Raja Grafindo Persada

Noeng Muhadjir., 2000. Metodologi Penelitian Kualitatif. Bandung: PT Remaja Rosdakarya.

Peraturan Menteri Pendidikan Nasional RI No 13 Tahun 2007 tentang Kepala Sekolah: Jakarta Nomor 39 tahun 2008 tentang Pembinaan Kesiswaan Pada Bab 1 pasal 1: Jakarta Nomor 62 Tahun 2014, Tentang Pedoman penyelenggaraan

Ekstrakurikuler Wajib Pendidikan Kepramukaan: Jakarta

Nomor 81A Tahun 2013 tentang Implementasi

Kurikulum menegaskan bahwa pelaksanaan Kurikulum 2013.

Undang-Undang Nomor 20 Tahun 2003 Tentang Sistem Pendidikan Nasional. Bandung: Citra Umbara 